\title{
Yerel Yönetimlerin Spor Tesislerinden Faydalanan Yöre Halkının Hizmet Kalitesi Beklentisi ve Algısına Yönelik Bir İnceleme: Keçiören Belediyesi Örneği ${ }^{*}$
}

\author{
Gülçin TANRIKULU ${ }^{1}$, Sümmani EKİCi $\dot{1}^{22}$ (D)
}

\author{
${ }^{1}$ Bilim Uzmanı, Muğla. \\ ${ }^{2}$ Muğla Sttk1 Koçman Üniversitesi, Spor Bilimleri Fakültesi, Muğla.
}

Orijinal Makale

Gönderi Tarihi: 25.12.2019
Kabul Tarihi: 17.03.2020
DOI: 10.25307/jssr.664936

Online Yayın Tarihi: 30.06 .2020

\section{Öz}

Bu çalışmanın amacı, Ankara Keçiören Belediyesi'ne bağlı spor tesisleri üyelerinin, bu merkezlerin sunduğu spor hizmetlerinin kalitesinden duyduğu beklenti ve alg1 düzeylerinin incelenmesidir. Ankara Keçiören Belediyesi'ne bağlı 4 Spor Merkezi araştırmanın çalışma evrenini, 356 kadın ve 129 erkek üyesi ise örneklemini oluşturmaktadır. Spor tesisleri merkezlerinin hizmet kalitesi algılarını ve beklentilerini belirlemek için ölçüm aracı olarak Gürbüz ve diğerleri (2005) tarafindan geçerliliği ve güvenirliği Türkiye için yapılmıș olan, Hizmet Kalitesi Değerlendirme Ölçeği (Service Quality Assessment Scale) kullanılmıştır. Bu ölçek personel, program, soyunma odası, fiziksel tesis, antrenman tesisi alt boyutlarından oluşmaktadır. Elde edilen verilerle, frekans, yüzde değeri, aritmetik ortalaması ve standart sapma analizleri yapılmış, ölçeğin iç tutarlılığının belirlenebilmesi için güvenirlilik katsayısı yöntemi ile veriler hesaplanmıştır. Genel olarak hizmet kalitesini belirleyebilmek için algılama skorları beklenti skorlarından çıkarılarak arasındaki farklar tespit edilmiş, gruplar arası farklılıkları bulmak için "eşleştirilmiş-örneklem $t$ testi, bağımsız örneklem $t$ testi ve tek yönlü varyans analizi" kullanılmıştır. Sonuç olarak, hizmet kalitesi genel olarak değerlendirildiğinde, algı-beklenti arasındaki fark -0,49 olup, bu değer spor merkezi müşterilerinin beklentilerinin tam olarak karşılanamadığı sonucunu ortaya çıkarmıştır.

Anahtar kelimeler: Yerel yönetim, hizmet kalitesi, alg1, beklenti.

\section{An Examination of the Local Benefits from Sport Facilities of Local Governments Public Expectation and Perception of Service Quality: Case of Kecioren Municipality}

\begin{abstract}
The aim of this study is to determine the expectations and perceptions of the members of sports facilities of Ankara Keçiören Municipality. The study population of the 4 Sport Centers of Ankara Keçiören Municipality is composed of 356 female and 129 male members. Sports facilities, centers of service quality perceptions and Gürbüz et al. (2005) as a measurement tool to determine their expectations made for the validity and reliability of Turkey, Service Quality Assessment Scale was used. This scale consists of sub-dimensions of personnel, program, dressing room, physical facility and training facility. With the obtained data, frequency, percentage value, arithmetic mean and standard deviation analyzes were performed and the data were calculated with the reliability coefficient method to determine the internal consistency of the scale. In order to determine the service quality in general, the differences between the perception scores were subtracted from the expectation scores and "paired-sample $t$ test, independent sample $t$ test and one-way analysis of variance were used to find the differences between the groups. As a result, when the service quality is evaluated in general, the difference between perception and expectation is -0.49 , and this value has come to the conclusion that the expectations of the sports center customers are not fully met.
\end{abstract}

Keywords: Local government, service quality, perception, expectation.

\footnotetext{
*Bu çalışma, Gülçin Tanrıkulu tarafından Muğla Sıtkı Koçman Üniversitesi Sosyal Bilimler Enstitüsü Spor Yöneticiliği Anabilim Dalında aynı isimle sunulmuş olan Yüksek Lisans tezinden türetilmiştir.

† Sorumlu Yazar: Sümmani EKİCI, Doç. Dr., Muğla Sıtkı Koçman Üniversitesi, Spor Bilimleri Fakültesi. E-posta: ekicis@gmail.com.
} 
Tanrıkulu, G. ve Ekici, S. (2020). Yerel yönetimlerin spor tesislerinden faydalanan yöre halkının hizmet kalitesi beklentisi ve algısına yönelik bir inceleme: Keçiören Belediyesi örneği. Spor Bilimleri Araşstırmaları Dergisi, 5(1), 15-26.

\section{GÍRIŞ}

Hizmet, müşteri beklentilerini karşılamak maksadıyla mal ve hizmet satan, kuruluş ve bireylerin uygulamakta olduğu eylemlerdir. Hizmet uygulaması, iki şekilde yapılır; birinci olarak müşteriye kaliteli mal ve hizmet sunmak, ikincisi ise müşteri memnuniyeti için yer verilen uygulamalardır (Arabac1, 2010).

Hizmette, sunan ve sunulan taraflar bulunmakta; hizmeti sunan 'hizmet sağlayan', hizmet sunulan ise 'müşteri' olarak ifade edilmektedir. Müşteri denildiğinde çoğunlukla 'bir malı veya hizmeti satın alan kişi' akla gelmektedir. Ancak özel olarak incelendiğinde müşteri; bir mal veya hizmetten ücret ödeyerek faydalanmanın yanında, ücret ödemeden de o mal veya hizmetten faydalanan kişi anlamına gelebilmektedir. Örneğin, kar amacı güden bir özel organizasyonda ücret karşılığında bir spor hizmetinden faydalanmanın yanında, kar amacı gütmeyen bir kamu organizasyonundaki bir spor hizmetinden ücretsiz olarak faydalanılabilir (Y1ld1z, 2008).

Literatüre göz atıldığında, hizmet kalitesinin kavramsallaştırılmasına yönelik çalışmaların 80'li yıllarda yoğunlaştığı görülmektedir. Grönroos (1984) hizmet kalitesinin teknik kalite, fonksiyonel kalite ve firma imajından oluştuğunu, bu boyutlar çerçevesinde verilen bir hizmetin kalitesinin, tüketicinin beklentisi ile algısının karşılaştırıldığı bir değerlendirme işleminin sonucunda ortaya çıktığını ileri sürmüştür. Daha sonra bir dizi çalışmalar yürüten Parasuraman ve diğerleri $(1985,1988$, 1994) hizmet kalitesine daha geniş bakış açısıyla yaklaşmış ve "somut özellikler, güvenirlik, heveslilik, güven ve empati” boyutlarından oluşan SERVQUAL modelini geliştirmişlerdir. $\mathrm{Bu}$ modelde müşterilerin işletmelerden "ne bekledikleri" ile "ne aldıkları" arasındaki farklılığa odaklanmışlardır. Daha sonra, Cronin ve Taylor (1992, 1994), SERVPERF adını verdikleri "performans temelli" bir hizmet kalitesi modeli geliştirmişler, SERVQUAL modelinde bulunan "beklentiler"in müşterilerin zaten zihninde yer aldığını, dolayısıyla bu ölçüme gerek olmadığını ileri sürmüşlerdir. Günümüzde her iki model de çeşitli sektörlerde yapılan çalışmalarda yaygın kullanım alanı bulmuştur (Yıldız, 2008). Bu modeller spor alanında bir dönem kullanılsa da (MacKay ve Crompton, 1988), sonrasında spor hizmetlerine yönelik özel ölçekler geliştirilmiş ve spor sektöründeki araştırmalarda yeni ölçekler kullanılmaya başlanmıştır (Yıldız, 2009).

Hizmet sektöründe spor ve fiziksel aktivite hizmetleri önemli bir yer tutmaktadır. 20. yüzyıldan başlayarak gelişen ve geliştikçe de çeşitlenen bu aktiviteler, günümüzde toplumların ilgilerini daha fazla çekerek kitleleri arkasından sürüklemektedir. Dolayısıyla yükselen ilgi sporu bir endüstri haline getirmiştir (Yıldız, 2009). Bu endüstri dalına ilişkin spor tesisleri ise, sportif faaliyetlerin ve organizasyonların yapıldığı, sporu yapanlar ve seyir açısından katılanlar için her türlü ihtiyaçlarının karşılanmasına imkan sağlayan doğal ya da yapay olarak inşa edilebilen ve içinde spor eğitiminin de yapıldığı açık ve kapalı alanlar olarak tanımlanmaktadır (Eroğlu, 2012). Atalı (2015) tarafından belediyelerin stratejik planlarının incelenmesi amacıyla yapılan çalışmada, halka yönelik sportif ifadelerin "ulusal ve uluslararası organizasyon düzenlemek", "spor tesisi yapmak" ve "rekreasyon alanları oluşturmak" olduğu, bunun yanında amaçlarının "spor faaliyetleri kent geneline yaymak", "kentin spor şehri olmasını sağlamak" ve "sağlıklı toplum ve nesiller yetiştirmek" olduğu ifade edilmiştir. 
Tanrıkulu, G. ve Ekici, S. (2020). Yerel yönetimlerin spor tesislerinden faydalanan yöre halkının hizmet kalitesi beklentisi ve algısına yönelik bir inceleme: Keçiören Belediyesi örneği. Spor Bilimleri Araştırmaları Dergisi, 5(1), 15-26.

Hizmet kalitesi, müşterilerin hizmet algıları ve beklentileri arasındaki farklılığın yönü ve derecesidir (Parasuraman vd., 1985). Bu sebeple işletmeler, müşterilerin algıları ile beklentileri arasındaki farklılığın azalması için, hizmet kalitesini geliştirmek ve devamlılığını sağlamakla yükümlüdürler.

Alan yazında, kamuya ait spor tesislerine yönelik, hizmet kalitesi ile ilgili sınırlı sayıda çalışma bulunmaktadır. Hizmet kalitesinin ölçümü verimli ve doğru olmasa bile, hizmet kalitesini geliştirmek için etkin ve uygun strateji geliştirmek ilk adımdır (Gürbüz, 2003). Türkiye'de spor hizmet kalitesi ile ilgili, özellikle kamusal alanda hizmet kalitesini ölçen araştırmaların azlığı sebebiyle bu araştırmanın yapılmasına ihtiyaç duyulmuştur. Yerel yönetimler, spor konusunda halkın memnuniyetini ön planda tutarak, spor tesislerinde, hizmet kalitesini artırmak, mevcut katılımcı sayısını artırmak ve aynı zamanda yeni katılımcı kazanmak için gerekli ve yeterli çabayı göstermelidir. Bu noktadan hareketle bu araştırmanın amacı, Ankara Keçiören Belediyesine bağlı Spor Merkezleri müşterilerinin, bu merkezlerin sunduğu spor hizmetleri ile ilgili algılanan ve beklenen hizmet kalitesi algılarını tespit ederek, cinsiyet, medeni durum, eğitim durumu, hane gelir düzeyi, ulaşım süresi, kullanım sıklığı, üyelik süresi spor merkezlerine göre hizmet kalitesi bakımından anlamlı farklılık olup olmadığını belirlemek ve bu bilgiler doğrultusunda, belediyenin spor merkezleri ile ilgili neler yapabileceği konusunda önerilerde bulunmaktır. Bu bakımdan, spor işletmelerinde de hizmet kalitesinin belirlenmesi ve işletmelerin hizmet kalitesini nasıl geliştirebileceği konusunda bilinçlendirilmesi önemlidir.

Literatür taraması sonucu spor tesisi müşterilerinin memnuniyeti, algı ve beklenti düzeyleri arasındaki farkı ele alan bu çalışmanın benzerine pek rastlanmadığı için önem kazandığını söyleyebiliriz. Ayrıca bu çalışma, daha sonra yapılacak benzer çalışmalara kaynak oluşturabilmesi bakımından da önemli görülmektedir.

\section{Yöntem}

Araştırma Modeli: Bu çalışma nicel araştırma yöntemlerinden betimsel ve ilişkisel tarama modeli kapsamında tasarlanmıştır.

Araştırmanın Çalışma Evreni: Ankara Keçiören Belediyesi'ne bağlı 4 adet Spor Merkezi (Kalaba, Aktepe, Etlik, Ovacık) spor faaliyetlerine katılan üyeler oluşturmuştur.

Araştırma Örneklemi: Ankara Keçiören Belediyesi'ne bağlı 4 spor Merkezi'ne (Kalaba, Aktepe, Etlik, Ovacık) devam eden 356 kadın ve 129 erkek üyeler oluşturmuştur. Bu kişiler 4 Spor Merkezi'nin spor faaliyetlerine, (Fitness, Yüzme Havuzu, Pilates, Zumba, Sauna ve Kreş) katılan ve rastlantısal örnekleme yöntemiyle seçilmiş bireylerdir. Katılımcıların tamamı, araştırmaya gönüllü olarak katılmışlardır.

Veri Toplama Aracı: Bu çalışmada, Lam, Zhang ve Jensen (2005) tarafından sağlık ve fitness kulüplerinin hizmet kalitesini değerlendirmek amacıyla geliştirilen, Gürbüz, Koçak ve Lam (2005) tarafından da Türkçe geçerlik ve güvenirlik çalışması yapılan SQAS (Service Quality Assessment Scale - Hizmet Kalitesi Değerlendirme Ölçeği) kullanılmıştır. Bu ölçek personel (9 madde), program (7 madde), soyuma odası (5 madde), fiziksel tesis ( 7 madde) ve 
Tanrıkulu, G. ve Ekici, S. (2020). Yerel yönetimlerin spor tesislerinden faydalanan yöre halkının hizmet kalitesi beklentisi ve algısına yönelik bir inceleme: Keçiören Belediyesi örneği. Spor Bilimleri Araştırmaları Dergisi, 5(1), 15-26.

antrenman tesisi (6 madde) alt boyutlarından oluşmaktadır. Ölçekte ters madde bulunmamaktadır. Araştırmaya katılan spor tesisi üyelerinin cinsiyet, medeni durum, eğitim durumu, hane gelir düzeyi, kullanım sıklığı, üyelik süresi, sportif programlara katılım amacı ve spor tesisleri ile ilgili bilgileri elde etmek için kişisel bilgi formu kullanılmıştır.

İstatistiksel Analiz: Elde edilen verilere, frekans, yüzde değeri, aritmetik ortalama ve standart sapma analizleri yapılmış, 4 ölçeğin iç tutarlılığının belirlenebilmesi için Cronbach Alpha güvenirlik katsayısı hesaplanmıştır. Genel olarak hizmet kalitesini belirleyebilmek için algılama skorları beklenti skorlarından çıkarılarak arasındaki farklar tespit edilmiştir. Gruplar arası farklılıkları bulmak için "eşleştirilmiş- örneklem t testi” ve "bağımsız örneklem t testi" kullanılmıştır.

\section{BULGULAR}

Çalışmanın bu bölümünde istatistiksel analizler sonucun elde edilen bulgulara ve yorumlarına yer verilmiştir.

\section{Demografik Özellikler}

Üyelerin çoğunluğunun kadın $(\% 73,4)$, evli $(\% 53,6)$ ve yükseköğretime sahip olduğu $(\% 52,2), 30-39$ yaş aralığında $(\% 31,8)$ bulunduğu ve ayrıca gelir düzeyinin 2001-3000 TL $(\% 35,5)$ olduğu görülmektedir (Tablo 1).

Tablo 1. Demografik özelliklere göre dağılımlar

\begin{tabular}{llcc}
\hline Değişkenler & & f & \% \\
\hline \multirow{2}{*}{ Cinsiyet } & Erkek & 129 & 26,6 \\
& Kadın & 356 & 73,4 \\
Medeni Durum & Evli & 260 & 53,6 \\
& Bekar & 225 & 46,4 \\
Eğitim Durumu & İlköğretim & 29 & 6 \\
& Ortaöğretim & 203 & 41,9 \\
& Yükseköğretim & 253 & 52,2 \\
& 19 ve altı & 40 & 8,2 \\
Yaş & 20-29 yaş & 155 & 32 \\
& 30-39 yaş & 154 & 31,8 \\
& $40-49$ yaş & 109 & 22,5 \\
& 50-59 yaş & 26 & 5,4 \\
& 60 ve üstü & 1 & 0,2 \\
Gelir & 2000 TL ve altı & 127 & 26,2 \\
& $2001-3000$ TL aras1 & 172 & 35,5 \\
& 3001-4000 TL aras1 & 93 & 19,2 \\
& $4001-5000$ TL aras1 & 52 & 10,7 \\
\hline
\end{tabular}

\section{Programla İlgili Özellikler}

Üyelerin büyük çoğunluğunun fitness programlarına katıldığı $(\% 63,7)$ ve sürelerinin 6 aydan daha az olduğu $(\% 35,1)$, yine büyük çoğunluğunun sağlıklı ve zinde kalmak $(\% 44,3)$ amacıyla spor hizmetini aldıkları Tablo 2'den anlaşılmaktadır. 
Tanrıkulu, G. ve Ekici, S. (2020). Yerel yönetimlerin spor tesislerinden faydalanan yöre halkının hizmet kalitesi beklentisi ve algısına yönelik bir inceleme: Keçiören Belediyesi örneği. Spor Bilimleri Araştırmaları Dergisi, 5(1), 15-26.

Tablo 2. Programla ilgili özelliklere göre dağılımlar

\begin{tabular}{llcc}
\hline Değişkenler & & f & \% \\
\hline Programa Katılma Süresi & 6 aydan daha az & 170 & 35,1 \\
& 6 ay - 1 yıl & 57 & 11,8 \\
& $1-2$ yıl & 80 & 16,5 \\
& $2-3$ yıl & 49 & 10,1 \\
Program Özelliği & 3 ylldan fazla & 129 & 26,6 \\
& Fitness & 309 & 63,7 \\
& Havuz & 108 & 22,3 \\
& Pilates & 35 & 7,2 \\
& Zumba & 33 & 6,8 \\
& Sağllklı olmak/Zinde kalmak & 215 & 44,3 \\
& Güçlenmek & 44 & 9,1 \\
& Kilo kontrolü & 105 & 21,6 \\
& Sosyal çevre kazanmak & 14 & 2,9 \\
& Güzel/Narin görünmek & 31 & 6,4 \\
& Vücut geliştirmek & 36 & 7,4 \\
& Rahatlamak & 24 & 4,9 \\
& Boş zamanı değerlendirmek & 16 & 3,3 \\
\hline
\end{tabular}

\section{Korelasyon Analizi}

Korelasyon analizine göre, katılımcıların gelirleri arttıkça beklentileri de artmaktadır $(\mathrm{p}<0,05)$. Benzer şekilde, program süresi arttıkça katılımcıların beklentileri de artmaktadır ( $\mathrm{p}<0,05)$, (Tablo 3). Yani, yüksek gelirliler daha yüksek kalite beklentisine sahiptirler. Tesislerden daha uzun süreli yararlanmak isteyen katılımcılar da yüksek kalite beklentisine sahiptirler.

Tablo 3. Korelasyon sonuçları

\begin{tabular}{lccccccc}
\hline Değişkenler & 1 & 2 & 3 & 4 & 5 & 6 & 7 \\
\hline 1.Cinsiyet & 1 & & & & & & \\
2.Yas &, 009 & 1 & & & & & \\
3.Medeni &, 008 &,$- 580^{* * *}$ & 1 & & & & \\
4.Eğitim &,- 042 &,$- 164^{* * *}$ &, $219^{* *}$ & 1 & & & \\
5.Gelir &,- 068 &, $122^{* *}$ &,$- 175^{* *}$ &, $150^{* *}$ & 1 & & \\
6.Program süresi &,$- 178^{* * *}$ &, $310^{* *}$ &,$- 196^{* *}$ &, 072 &, $135^{* *}$ & 1 & \\
7.Alg1 &, $267^{* *}$ &, 050 &,- 006 &,- 088 &, 000 &,- 025 & 1 \\
8.Beklenti &, 043 &,- 047 &, 055 &, 074 &, $111^{*}$ &, $091^{*}$ &, $242^{* *}$ \\
\hline${ }^{* *} \mathrm{p}<0,01 ; " \mathrm{p}<0,05$ & & & & & & &
\end{tabular}

\section{Hizmet Kalitesine Yönelik Algılama ve Beklenti Değerleri}

Personel alt boyutunun algılama değeri 4,27 ile iyi düzeyde olduğu görülmektedir. Beklenti değeri ise 4,46'dır. İki değer arasındaki fark -0,19'dur ( $\mathrm{p}<0,001)$. Maddeler içerisinde sadece "yardım etme istekliliğii" maddesinde pozitif fark söz konusudur $(0,7)$. Maddeler içerisinde en fazla fark "şikayetlere karşı duyarlılık" maddesine aittir (-0,37). Dolayısıyla, personel alt boyutu içerisinde "yardım etme istekliliğgi" maddesi hariç, diğer tüm maddeler iyileştirilmesi gereken alanlar olarak değerlendirilebilir.

Program alt boyutunun algılama değeri 4,10 ile iyi düzeyde olduğu görülmektedir. Beklenti değeri ise 4,65'tir. İki değer arasındaki fark $-0,4$ 'tür $(p<0,001)$. Maddeler içerisinde sadece "program zaman çizelgesinin uygunluğu" maddesinde pozitif fark söz konusudur $(0,2)$. Maddeler içerisinde en fazla fark "yeterli alan" maddesine aittir (-0,55). Dolayısıyla, program alt boyutu içerisinde "program zaman çizelgesinin uygunluğu" maddesi hariç, diğer tüm maddeler iyileştirilmesi gereken alanlar olarak değerlendirilebilir. Soyunma odası alt boyutunun algılama değeri 4,18 ile iyi düzeyde olduğu görülmektedir. Beklenti değeri ise 
Tanrıkulu, G. ve Ekici, S. (2020). Yerel yönetimlerin spor tesislerinden faydalanan yöre halkının hizmet kalitesi beklentisi ve algısına yönelik bir inceleme: Keçiören Belediyesi örneği. Spor Bilimleri Araştırmaları Dergisi, $5(1), 15-26$.

4,58'tir. İki değer arasındaki fark $-0,55$ 'tir $(\mathrm{p}<0,001)$. Maddeler içerisinde sadece "dolapların bulunması ve erişim" maddesinde pozitif fark söz konusudur $(0,45)$. Maddeler içerisinde en fazla fark "duşların temizliği" maddesine aittir $(-0,67)$. Dolayısıyla, program alt boyutu içerisinde "dolapların bulunması ve erişim" maddesi hariç, diğer tüm maddeler iyileştirilmesi gereken alanlar olarak değerlendirilebilir.

Fiziksel tesis alt boyutunun algilama değeri 4,04 ile iyi düzeyde olduğu görülmektedir. Beklenti değeri ise 4,57'tir. İki değer arasındaki fark -0,53'tür ( $\mathrm{p}<0,001)$. Maddeler içerisinde sadece "yerin uygunluğu" maddesinde pozitif fark söz konusudur $(0,27)$. Maddeler içerisinde en fazla fark "park alanının emniyeti" maddesine aittir $(-0,79)$. Dolayısıyla, personel alt boyutu içerisinde "yerin uygunluğu" maddesi hariç, diğer tüm maddeler iyileştirilmesi gereken alanlar olarak değerlendirilebilir.

Antrenman tesis alt boyutunun algilama değeri 3,81 ile iyi düzeyde olduğu görülmektedir. Beklenti değeri ise 4,60'tır. İki değer arasındaki fark $-0,79$ 'dur $(\mathrm{p}<0,001)$. Maddeler içerisinde sadece "aletlerin çeşitliliği”" maddesinde pozitif fark söz konusudur $(0,8)$. Maddeler içerisinde en fazla fark "genel bakım" maddesine aittir $(-0,98)$. Dolayısıyla, personel alt boyutu içerisinde "aletlerin çeşitliliği" maddesi hariç, diğer tüm maddeler iyileştirilmesi gereken alanlar olarak değerlendirilebilir.

Tablo 4. Hizmet kalitesi ve altboyutlarına yönelik algılama-beklenti değerleri

\begin{tabular}{|c|c|c|c|c|c|c|c|}
\hline & \multicolumn{2}{|c|}{ Algılama } & \multicolumn{2}{|c|}{ Beklenti } & \multirow{2}{*}{$\mathbf{A}-\mathbf{B}$} & \multirow{2}{*}{$\mathbf{t}$} & \multirow[b]{2}{*}{$\mathbf{p}$} \\
\hline Maddeler & $\mathbf{X}$ & SS & $\mathbf{X}$ & SS & & & \\
\hline Personel & 4,27 & ,67 & 4,46 & ,48 & $-0,19$ & $-5,946$ & $0,000 *$ \\
\hline 1.Gerekli bilgi/becerilere sahip olma & 4,29 & ,84 & 4,65 &, 53 & $-0,36$ & $-8,432$ & $0,000 *$ \\
\hline 2.Temizlik ve iyi giyim & 4,35 &, 77 & 4,62 &, 53 & $-0,27$ & $-7,483$ & $0,000 *$ \\
\hline 3.Yardım etme istekliliği & 4,30 & ,82 & 3,60 & 1,37 & 0,7 & 9,991 & $0,000 *$ \\
\hline 4.Sabir & 4,29 & ,80 & 4,63 & ,53 & $-0,34$ & $-8,584$ & $0,000 *$ \\
\hline 5.Üyelerle iletişim & 4,28 & ,83 & 4,64 & ,52 & $-0,36$ & $-8,877$ & $0,000 *$ \\
\hline 6.Şikâyetlere karş1 duyarlılık & 4,25 & 87 & 4,62 & ,56 & $-0,37$ & $-8,439$ & $0,000 *$ \\
\hline 7.Nezaket & 4,31 & ,77 & 4,58 & 60 & $-0,27$ & $-6,746$ & $0,000 *$ \\
\hline 8.Üyelere özel ilgi gösterilmesi & 4,08 & 1,04 & 4,25 & ,93 & $-0,17$ & $-3,446$ & $0,001 *$ \\
\hline 9.Hizmet sunumu sürekliliği & 4,24 & ,86 & 4,50 & ,63 & $-0,26$ & $-6,087$ & $0,000 *$ \\
\hline Cronbach Alpha & \multicolumn{2}{|c|}{,926 } & \multicolumn{2}{|c|}{, 827} & & & \\
\hline Program & 4,18 & ,66 & 4,58 & ,46 & $-0,4$ & $-12,099$ & $0,000 *$ \\
\hline 10.Program çeşitliliği & 4,25 &, 79 & 4,56 &, 59 & $-0,31$ & $-7,698$ & $0,000 *$ \\
\hline 11.Programların uygun düzeyde olması & 4,30 & ,72 & 4,58 & 57 & $-0,28$ & $-7,299$ & $0,000 *$ \\
\hline 12.Program zaman çizelgesinin uygunluğu & 4,35 & 69 & 4,55 & ,57 & $-0,2$ & $-5,438$ & $0,000 *$ \\
\hline 13.Programların içerik kalitesi & 4,18 & ,86 & 4,60 & ,56 & $-0,42$ & $-9,226$ & $0,000 *$ \\
\hline 14.Sınıf büyüklüğünün uygunluğu & 4,09 & ,92 & 4,60 & 60 & $-0,51$ & $-10,729$ & $0,000 *$ \\
\hline 15.Fon müziği (varsa) & 3,98 & 1,05 & 4,51 &, 74 & $-0,53$ & $-9,681$ & $0,000 *$ \\
\hline 16.Yeterli alan & 4,12 & ,98 & 4,67 &, 50 & $-0,55$ & $-11,215$ & $0,000^{*}$ \\
\hline Cronbach Alpha & \multicolumn{2}{|c|}{, 882} & \multicolumn{2}{|c|}{, 887} & & & \\
\hline Soyunma Odast & 4,10 & ,72 & 4,65 &, 44 & $-0,55$ & $-15,409$ & $0,000 *$ \\
\hline 17.Dolapların bulunması & 4,18 & ,90 & 4,63 &, 52 & $-0,45$ & $-10,003$ & $0,000 *$ \\
\hline 18.Genel bakım & 4,00 & 1,05 & 4,65 &, 52 & $-0,65$ & $-12,628$ & $0,000 *$ \\
\hline 19.Duşların temizliği & 4,01 & ,99 & 4,68 &, 51 & $-0,67$ & $-13,219$ & $0,000 *$ \\
\hline 20.Erişim & 4,20 & ,84 & 4,65 &, 53 & $-0,45$ & $-10,431$ & $0,000 *$ \\
\hline 21.Emniyet & 4,10 & ,93 & 4,66 & ,51 & $-0,56$ & $-11,856$ & $0,000 *$ \\
\hline Cronbach Alpha & \multicolumn{2}{|c|}{, 820} & \multicolumn{2}{|c|}{, 906} & & & \\
\hline
\end{tabular}

$\mathrm{A}=$ Algılama, B=Beklenti, ${ }^{*} \mathrm{p}<0,001$

Genel hizmet kalitesi algılama değeri 4,08 ile iyi düzeyde olduğu görülmektedir. Beklenti değeri ise 4,57'dir. İki değer arasındaki fark -0,49 birim ve negatif yönde bir farkın olduğu, istatistiksel açıdan ise $\mathrm{p}<0,001$ düzeyinde anlamlı bir farklılığın olduğu tespit edilmiştir. 
Tanrıkulu, G. ve Ekici, S. (2020). Yerel yönetimlerin spor tesislerinden faydalanan yöre halkının hizmet kalitesi beklentisi ve algısına yönelik bir inceleme: Keçiören Belediyesi örneği. Spor Bilimleri Araştırmaları Dergisi, 5(1), 15-26.

Tablo 4 (Devamı). Hizmet kalitesi ve altboyutlarına yönelik algılama-beklenti değerleri

\begin{tabular}{|c|c|c|c|c|c|c|c|}
\hline & \multicolumn{2}{|c|}{ Algılama } & \multicolumn{2}{|c|}{ Beklenti } & \multirow{2}{*}{$\mathbf{A}-\mathbf{B}$} & \multirow{2}{*}{$\mathbf{t}$} & \multirow[b]{2}{*}{$\mathbf{p}$} \\
\hline Maddeler & $\mathbf{X}$ & SS & $\mathbf{X}$ & SS & & & \\
\hline Fiziksel Tesis & 4,04 &, 75 & 4,57 & ,46 & $-0,53$ & $-14,320$ & $0,000 *$ \\
\hline 22.Yerin uygunluğu & 4,29 & , 78 & 4,56 &, 58 & $-0,27$ & $-6,457$ & $0,000 *$ \\
\hline 23.Etkinlik saatleri & 4,24 &, 88 & 4,58 &, 56 & $-0,34$ & $-7,877$ & $0,000^{*}$ \\
\hline 24.Otopark olması & 3,88 & 1,22 & 4,49 & ,68 & $-0,61$ & $-9,871$ & $0,000 *$ \\
\hline 25.Binaya erişim & 4,20 & ,93 & 4,58 &, 55 & $-0,38$ & $-8,354$ & $0,000^{*}$ \\
\hline 26.Park alanının emniyeti & 3,78 & 1,17 & 4,57 &, 58 & $-0,79$ & $-13,608$ & $0,000 *$ \\
\hline 27.S1cakl1k kontrolü & 4,00 & 1,14 & 4,61 &, 52 & $-0,61$ & $-10,664$ & $0,000^{*}$ \\
\hline 28.Işık kontrolü & 3,90 & 1,21 & 4,64 & 60 & $-0,74$ & $-12,498$ & $0,000^{*}$ \\
\hline Cronbach Alpha & \multicolumn{2}{|c|}{, 832} & \multicolumn{2}{|c|}{,906 } & & & \\
\hline Antrenman Tesisi & 3,81 & ,98 & 4,60 & ,46 & $-0,79$ & $-16,764$ & $0,000 *$ \\
\hline 29.Ortamın cazipliği & 3,99 & 1,05 & 4,54 & 60 & $-0,55$ & $-11,103$ & $0,000^{*}$ \\
\hline 30.Modern görünümlü aletler & 3,78 & 1,21 & 4,53 &, 59 & $-0,75$ & $-12,793$ & $0,000^{*}$ \\
\hline 31.İşaret ve talimatların yeterliliği & 3,81 & 1,18 & 4,58 &, 56 & $-0,77$ & $-13,659$ & $0,000 *$ \\
\hline 32.Aletlerin çeşitliliği & 3,83 & 1,14 & 4,63 &, 52 & $-0,8$ & $-14,449$ & $0,000 *$ \\
\hline 33.Antrenman tesisi/ekipmanı bulunmas1 & 3,76 & 1,20 & 4,62 &, 56 & $-0,86$ & $-14,620$ & $0,000^{*}$ \\
\hline 34.Genel bakım & 3,69 & 1,28 & 4,67 &, 52 & $-0,98$ & $-15,659$ & $0,000 *$ \\
\hline Cronbach Alpha & \multicolumn{2}{|c|}{,912 } & \multicolumn{2}{|c|}{,911 } & & & \\
\hline Genel Hizmet Kalitesi & 4,08 & ,63 & 4,57 & ,40 & $-0,49$ & $-16,250$ & $0,000 *$ \\
\hline
\end{tabular}

\section{Algılama ve Beklenti Değerlerinin Cinsiyete Göre Karşılaştırılması}

Cinsiyete göre hizmet kalitesi algılarının karşılaştırılmasında tüm alt boyutlarda kadın katılımcılar lehine anlamlı farklılıklar $(\mathrm{p}<0,01)$ görülmüştür (Tablo 5).

Tablo 5. Cinsiyete göre hizmet kalitesi algılarının bağımsız örneklem t-testi değerleri

\begin{tabular}{|c|c|c|c|c|c|}
\hline Boyutlar & Gruplar & $\begin{array}{c}\text { Alg1 } \\
\text { X }\end{array}$ & SS & $\mathbf{t}$ & $\mathbf{p}$ \\
\hline \multirow{2}{*}{ Personel } & Erkek & 4,01 & ,70 & \multirow{2}{*}{$-3,380$} & \multirow{2}{*}{$0,001^{*}$} \\
\hline & Kadın & 4,25 & 64 & & \\
\hline \multirow{2}{*}{ Program } & Erkek & 3,94 & ,71 & \multirow{2}{*}{$-6,234$} & \multirow{2}{*}{$0,000^{*}$} \\
\hline & Kadın & 4,38 & 62 & & \\
\hline \multirow{2}{*}{ Soyunma Odası } & Erkek & 3,90 & 66 & \multirow{2}{*}{$-3,919$} & \multirow{2}{*}{$0,000^{*}$} \\
\hline & Kadın & 4,17 &, 73 & & \\
\hline \multirow{2}{*}{ Fiziksel Tesis } & Erkek & 3,76 & ,68 & \multirow{2}{*}{$-5,411$} & \multirow{2}{*}{$0,000^{*}$} \\
\hline & Kadın & 4,15 & 75 & & \\
\hline \multirow{2}{*}{ Antrenman Tesisi } & Erkek & 3,39 & ,99 & \multirow{2}{*}{$-5,670$} & \multirow{2}{*}{$0,000^{*}$} \\
\hline & Kadın & 3,96 & ,94 & & \\
\hline \multirow{2}{*}{ Genel Hizmet Kalitesi } & Erkek & 3,80 & ,59 & \multirow{2}{*}{$-6,180$} & \multirow{2}{*}{$0,000^{*}$} \\
\hline & Kadın & 4,18 & 61 & & \\
\hline
\end{tabular}

Tablo 6 da Cinsiyete göre hizmet kalitesi beklentilerinin karşılaştırılmasında hiçbir alt boyutta anlamlı farklılık tespit edilmemiştir ( $p>.05$ ) (Tablo 6). Ancak kadın katılımcıların ortalamalarının erkeklere göre yüksek olduğu gözlemlenmiştir.

Tablo 6. Cinsiyete göre hizmet kalitesi beklentilerinin bağımsız örneklem t-testi değerleri

\begin{tabular}{|c|c|c|c|c|c|}
\hline Boyutlar & Gruplar & $\begin{array}{l}\text { Beklenti } \\
\text { X }\end{array}$ & SS & $\mathbf{t}$ & p \\
\hline \multirow{2}{*}{ Personel } & Erkek & 4,41 & ,45 & \multirow{2}{*}{$-1,376$} & \multirow{2}{*}{, 170} \\
\hline & Kadın & 4,47 & 49 & & \\
\hline \multirow{2}{*}{ Program } & Erkek & 4,56 & 47 & \multirow{2}{*}{,- 644} & \multirow{2}{*}{, 521} \\
\hline & Kadın & 4,59 & 45 & & \\
\hline \multirow{2}{*}{ Soyunma Odası } & Erkek & 4,65 & 42 & \multirow{2}{*}{,- 203} & \multirow{2}{*}{,839 } \\
\hline & Kadın & 4,66 & 45 & & \\
\hline \multirow{2}{*}{ Fiziksel Tesis } & Erkek & 4,52 & ,44 & \multirow{2}{*}{$-1,502$} & \multirow{2}{*}{, 135} \\
\hline & Kadın & 4,59 & 47 & & \\
\hline \multirow{2}{*}{ Antrenman Tesisi } & Erkek & 4,58 & ,43 & \multirow{2}{*}{,- 524} & \multirow{2}{*}{,601 } \\
\hline & Kadın & 4,60 & ,48 & & \\
\hline \multirow{2}{*}{ Genel Hizmet Kalitesi } & Erkek & 4,54 & ,37 & \multirow{2}{*}{$-1,001$} & \multirow{2}{*}{,318 } \\
\hline & Kadın & 4,58 & 41 & & \\
\hline
\end{tabular}


Tanrıkulu, G. ve Ekici, S. (2020). Yerel yönetimlerin spor tesislerinden faydalanan yöre halkının hizmet kalitesi beklentisi ve algısına yönelik bir inceleme: Keçiören Belediyesi örneği. Spor Bilimleri Araştırmaları Dergisi, 5(1), 15-26.

\section{Algılama ve Beklenti Değerlerinin Eğitim Durumuna Göre Karşılaştırılması}

Eğitim durumuna göre hizmet kalitesi algılamaları karşılaştırıldığında hiçbir alt boyutta anlamlı farklılık bulunamamıştır ( $\mathrm{p}>.05)$, (Tablo 7).

Tablo 7. Eğitim durumuna göre hizmet algılarının tek boyutlu varyans analizi bulguları

\begin{tabular}{|c|c|c|c|c|c|c|}
\hline Boyutlar & $\begin{array}{l}\text { Değişim } \\
\text { Kaynağı }\end{array}$ & $\begin{array}{c}\text { Kareler } \\
\text { Toplamı }\end{array}$ & Sd & $\begin{array}{c}\text { Kareler } \\
\text { Ortalaması }\end{array}$ & $\mathbf{F}$ & $\mathbf{p}$ \\
\hline \multirow{3}{*}{ Personel } & Gruplar arası & 1,219 & 2 &, 609 & \multirow{3}{*}{1,337} & \multirow{3}{*}{,264 } \\
\hline & Grup içi & 219,663 & 482 & 456 & & \\
\hline & Toplam & 220,882 & 484 & & & \\
\hline \multirow{3}{*}{ Program } & Gruplar arası & 2,402 & 2 & 1,201 & \multirow{3}{*}{2,713} & \multirow{3}{*}{, 067} \\
\hline & Grup içi & 213,376 & 482 & ,443 & & \\
\hline & Toplam & 215,778 & 484 & & & \\
\hline \multirow{3}{*}{$\begin{array}{l}\text { Soyunma } \\
\text { Odası }\end{array}$} & Gruplar arası &, 250 & 2 &, 125 & \multirow{3}{*}{,237 } & \multirow{3}{*}{,789 } \\
\hline & Grup içi & 253,953 & 482 &, 527 & & \\
\hline & Toplam & 254,203 & 484 & & & \\
\hline \multirow{3}{*}{$\begin{array}{l}\text { Fiziksel } \\
\text { Tesis }\end{array}$} & Gruplar arası & 1,434 & 2 & ,717 & \multirow{3}{*}{1,268} & \multirow{3}{*}{,282 } \\
\hline & Grup içi & 272,672 & 482 & 566 & & \\
\hline & Toplam & 274,106 & 484 & & & \\
\hline \multirow{3}{*}{$\begin{array}{l}\text { Antrenman } \\
\text { Tesisi }\end{array}$} & Gruplar arası & 5,610 & 2 & 2,805 & \multirow{3}{*}{2,903} & \multirow{3}{*}{, 056} \\
\hline & Grup içi & 465,711 & 482 & ,966 & & \\
\hline & Toplam & 471,320 & 484 & & & \\
\hline
\end{tabular}

Eğitim durumuna göre hizmet kalitesi beklentileri karşılaştırıldığında hiçbir alt boyutta anlamlı farklılık bulunamamıştır (p>.05), (Tablo 8).

Tablo 8. Eğitim durumuna göre hizmet beklentilerinin tek boyutlu varyans analizi bulguları

\begin{tabular}{|c|c|c|c|c|c|c|}
\hline Boyutlar & Değişim Kaynağı & $\begin{array}{l}\text { Kareler } \\
\text { Toplamı }\end{array}$ & Sd & $\begin{array}{c}\text { Kareler } \\
\text { Ortalaması }\end{array}$ & $\mathbf{F}$ & $\mathbf{p}$ \\
\hline \multirow{3}{*}{ Personel } & Gruplar arası & ,963 & 2 &, 482 & \multirow{3}{*}{2,076} & \multirow{3}{*}{, 127} \\
\hline & Grup içi & 111,808 & 482 & 232 & & \\
\hline & Toplam & 112,771 & 484 & & & \\
\hline \multirow{3}{*}{ Program } & Gruplar arası &, 371 & 2 & , 186 & \multirow{3}{*}{,865 } & \multirow{3}{*}{,422 } \\
\hline & Grup içi & 103,359 & 482 & 214 & & \\
\hline & Toplam & 103,730 & 484 & & & \\
\hline \multirow{3}{*}{$\begin{array}{l}\text { Soyunma } \\
\text { Odası }\end{array}$} & Gruplar arası &, 506 & 2 & ,253 & \multirow{3}{*}{1,277} & \multirow{3}{*}{,280 } \\
\hline & Grup içi & 95,543 & 482 & 198 & & \\
\hline & Toplam & 96,050 & 484 & & & \\
\hline \multirow{3}{*}{$\begin{array}{l}\text { Fiziksel } \\
\text { Tesis }\end{array}$} & Gruplar arası &, 178 & 2 & ,089 & \multirow{3}{*}{,413 } & \multirow{3}{*}{,662 } \\
\hline & Grup içi & 103,712 & 482 & 215 & & \\
\hline & Toplam & 103,890 & 484 & & & \\
\hline \multirow{3}{*}{$\begin{array}{l}\text { Antrenman } \\
\text { Tesisi }\end{array}$} & Gruplar arası &, 533 & 2 & ,266 & \multirow{3}{*}{1,212} & \multirow{3}{*}{,299 } \\
\hline & Grup içi & 105,973 & 482 & 220 & & \\
\hline & Toplam & 106,505 & 484 & & & \\
\hline
\end{tabular}

\section{TARTIŞMA VE SONUÇ}

$\mathrm{Bu}$ araştırmada, yerel yönetimlerin sunduğu spor hizmetlerinden faydalanan üyelerin hizmet kalitesi düzeyleri ve algı-beklenti arasındaki farklar incelenmiştir. Bu kısımda, araştırmacının amacı doğrultusunda kullandığı ölçeğin sonuçları ile elde edilen verilerin istatistiksel analizleri sonucu elde edilen bulgulara ilişkin yorumlar, ulaşılan sonuçlar ve öneriler yer almaktadır. Bu bölümde çalışmaya katılan bireylerin, kişisel bilgileri ve anket sorularına vermiş oldukları cevaplara ilişkin bulgular yorumlanmıştır. 
Tanrıkulu, G. ve Ekici, S. (2020). Yerel yönetimlerin spor tesislerinden faydalanan yöre halkının hizmet kalitesi beklentisi ve algısına yönelik bir inceleme: Keçiören Belediyesi örneği. Spor Bilimleri Araştırmaları Dergisi, 5(1), 15-26.

Araştırmaya ilişkin kişisel bilgiler analiz sonuçları incelendiğinde, katılımcıların yarıdan fazlasının $(\% 73,4)$ kadın olduğu, aynı zaman da katılımcıların \%52,2'sinin yükseköğretim düzeyinde eğitime sahip olduğu tespit edilmiştir. Ayrıca katılımcıların sahip olması \%44,3'ünün sağlıklı ve zinde kalmak amacıyla spor merkezlerini kullandıkları belirlenmiştir. Spor merkezlerine yönelik yapılan alanyazın araştırmalarında da benzer sonuçlara rastlanılmaktadır (Afthinos vd., 2005; Lam vd., 2005; Rueangthanakiet, 2008). Katılımc1ların cinsiyet özelliklerine göre dağılımları incelendiğinde, kadınlar 356 kişi erkekler ise 129 kişi olduğu görülmüştür. Bu sonuçlar, kadınların erkeklere oranla daha çok fiziksel etkinliklere katıldıklarını ve eğitim düzeyi yüksek olan insanların sağlık ve egzersize daha fazla önem verdiklerini göstermektedir. Ayrıca sonuçlar motivasyonel açıdan sağlıklı ve zinde kalmanın, katılımcıların spor merkezinden yararlanma amacının başında geldiğini ortaya koymaktadır.

Katılımcıların medeni durumu incelendiğinde 260 kişinin evli, 225 kişinin bekar olduğu görülmüştür. Katılımcıların eğitim durumu incelendiğinde 29 kişinin ilköğretim mezunu, 203 kişinin ortaöğretim mezunu, 253 kişinin de yükseköğretim mezunu olduğu görülmektedir. Buna göre en çok katılımın ortaöğretim ve yükseköğretim mezunu kişilerden olduğu görülmektedir. Katılımcıların yaş özellikleri incelendiğinde, "19 ve altı 40 kişi”, "20-29 yaş arası 155 kişi”, "30-39 yaş arası 154 kişi”, "40-49 yaş arası 109 kişiı”, "50-59 yaş arası 26 kişi”, "60 ve üstü 1 kişi” dir. Buna göre en çok katılımın “30-39 yaş grubu” bireyler olduğu görülmektedir.

Araştırmaya katılanların gelir gruplarına göre dağılımlarına baktığımızda "2000 TL ve altı 127 kişinin”, “2001-3000 TL aras1 172 kişinin”, “3001-4000 TL arası 93 kişinin”, “40015000 TL arası 52 kişinin”, "5000 TL ve üstü 41 kişsinin” gelire sahip olduğu görülmektedir. Buna göre ankete katılan kişiler içerisinde geliri "2001-3000 TL olanların” daha çok olduğu görülmektedir.

Programla ilgili özelliklere göre dağılımlar incelendiğinde katılımcıların \%35,1'lik yüzdelikle 6 aydan daha az programa katılım süresi belirlenmiş. Katılımcıların \%63,7 si' fitness programını, katılımcıların \%22,3'ü yüzme havuzunu, \%7,2'si ise pilates programını \%6,8'i zumba program özelliğini seçmiştir.

Maddeler açısından değerlendirildiğinde, yüksek kalite düzeyinde "personel alt boyutunun" 4,27 ile en iyi düzeyde olduğu görülmüştür. Tatmin edici kalite düzeyine sahip tek madde ise "yardım etme istekliliğgi" maddesidir. Buradan, spor merkezinde hizmet kalitesi ile ilgili en az sorunun personellerle ilgili olduğu sonucu çıkarılmaktadır. Literatürde personelin kaliteli hizmet üretmesinin, işletmenin karlılığını artıran önemli bir unsuru olarak görülmektedir. $\mathrm{Bu}$ yüzden, işletme yönetimleri örneğin içsel pazarlama uygulamaları (Yıldız, 2011a) ve etkin liderlik ile çalışanların ekstra rol davranışlarını artırabilir (Yıldız, 2011b), bu da işletmenin sunduğu hizmet kalitesinin artmasına katkı sağlayabilir.

Hizmet kalitesi algılamaları boyutlar açısından değerlendirildiğinde, tüm boyutların negatif yönde bir farka sahip olduğu, boyutlar içerisinde en düşük kalite düzeyine sahip olan boyutun ise "antrenman tesisi” boyutu olduğu görülmüştür. Bu sonuç, spor merkezleri tarafindan özellikle antrenman tesisi boyutuna yönelik hizmet unsurlarının iyi kavranamamış olduğunu göstermektedir. Hizmet kalitesi genel olarak değerlendirildiğinde, spor merkezi müşterilerinin beklentilerinin tam olarak karşılanamadığı sonucu ortaya çıkmıştır. 
Tanrıkulu, G. ve Ekici, S. (2020). Yerel yönetimlerin spor tesislerinden faydalanan yöre halkının hizmet kalitesi beklentisi ve algısına yönelik bir inceleme: Keçiören Belediyesi örneği. Spor Bilimleri Araştırmaları Dergisi, 5(1), 15-26.

Alanyazında, küresel farklılaşmaların yaşandığı günümüz spor sektöründe işletmelerin sürdürülebilir bir yapıya sahip olmalarında hizmet kalitesinin itici bir faktör olduğu vurgulanmaktadır (Yıldız vd., 2016). Berry, Parasuraman ve Zeithaml (1994), ölçülemeyen kalitenin iyileştiremeyeceğini ileri sürmektedir. $\mathrm{Bu}$ açıdan bakıldığında, müşteri beklentilerinin karşılanması ve ihtiyaçlarının giderilmesi bir işletmenin müşterilerini elde tutma ve rekabet avantajı elde etme çabalarında önemli unsurlar olarak görülmektedir (Parasuraman vd., 1988). Bu açıdan bakıldığında, spor merkezleri yönetimlerinin öncelikle yapması gereken faaliyet, periyodik olarak hizmet kalitesi ölçümlerini yapmak (Yıldız ve Tüfekçi, 2010), negatif boşluklar çıkması durumunda en düşük kalite düzeyine sahip olan özelliklerden başlamak suretiyle hizmet kalitesini hızla iyileştirerek müşteri memnuniyetini sağlamaktır.

Halkın istek ve gereksinimlerine hassas davranarak halkın beğenisini ve desteğini sağlamak yerel yönetimler için önemli bir yere sahiptir. Spor endüstrisi içerisinde yer alan örgütler, iletişim becerisi yüksek, takım çalışmasına uygun, planlama ve organizasyon becerisi olan bireylere ihtiyaç duymaktadır. Yerel yönetimlerin saha ve tesis yatırımlarının özellikle kitleye ve rekreatif spor tesislerine yönelik olarak çeşitlilik kazanması önem arz etmektedir, burada görev alacak personelin spor eğitimi almış kişilerden olması ise önemli bir etken olarak görülmektedir (Yıldız, 2018). Bu sebeple spor hizmetleri de yerel yönetimler için önemli bir yere sahiptir. $\mathrm{Bu}$ önem sonucunda yerel yönetimler halkın istek ve talepleri doğrultusunda coğrafi, kültürel ve sosyo-ekonomik değişkenlere göre spor hizmetlerini çeşitlendirmesi, sporun etkilerinin olumlu yönde artmasına ve yerel halkın güvenini kazanmada etkili olacaktır (Yetim, 2018).

Belediyelerin hizmet yelpazesinin gelişmesi ve çeşitlenmesinde yerel halkın ihtiyaçları belirleyici rol oynamakta (Negiz, 2011) ve halkın sosyal, kültürel, sportif ihtiyaçlarını da dikkate alarak gerekli hizmetleri mali yapılarının elverdiği ölçüde sunmaktadır (Koçak, Arslan ve Eti, 2017). Yerel yönetimlerde vatandaşın beklediği hizmet kalitesinin yakalanması için vatandaşın belediyenin kararlarına katılması gerekmektedir. Çünkü hizmeti alan vatandaştır. Vatandaşın kararlara katılmasıyla talepler tespit edilir. Böylece vatandaşın beklediği hizmet kalitesine ulaşılır (Usta ve Memiş, 2010).

Yıldız (2018) yapmış olduğu araştırmada Türkiye'de uygulanan yerel yönetim yasalarında spor hizmetleriyle ilgili olarak yerel yönetimlere önemli görevler düştüğü ancak idari yapılanma noktasında yerel yönetimlerin zayıf kaldıklarını ifade etmiştir. Aynı araştırmada, spor hizmetlerinin idari yapılanmasının olmaması dolayısı ile spor hizmetleri konusunda durum tespitinin, teknik bilgisi olmayan kişiler tarafından yapılmasına neden olduğu aktarılmıştır. Ayrıca bu durumun temel sebepleri arasında yöneticilerin kaynak kullanımı noktasında öncelik alanlarına göre yönlendirme yaptıklarını göstermektedir.

Sonuç olarak, spor merkezlerinin hizmet kalitesine yönelik daha çok ölçek geliştirmeye yönelik çalışma yapıldığından, hizmet kalitesi değerlendirmesi bakımından bu çalışmanın literatüre katkı sağlayacağı kanaati taşımaktadır. Elde edilen bulgular, spor merkezlerini yöneten kişiler için hizmet faaliyetlerini ve tespit edilen müşteri ihtiyaçlarını yerine getirmek için performans standartları oluşturabilmelerini sağlayacak yararlı bir bilgi kaynağı olarak 
Tanrıkulu, G. ve Ekici, S. (2020). Yerel yönetimlerin spor tesislerinden faydalanan yöre halkının hizmet kalitesi beklentisi ve algısına yönelik bir inceleme: Keçiören Belediyesi örneği. Spor Bilimleri Araştırmaları Dergisi, 5(1), 15-26.

görülmektedir. $\mathrm{Bu}$ çalışmada gerçekleştirilen hizmet kalitesi incelemeleri, yöneticilere hizmetlerinin iyileştirilmesi gereken yönlerini belirlemede yardımcı olacağı düşünülmektedir.

Yayın Etiği: Mevcut çalışmanın yazım sürecinde "Yükseköğretim Kurumları Bilimsel Araştırma ve Yayın Etiği Yönergesi" kapsamında bilimsel, etik ve alıntı kurallarına uyulmuş olup; toplanan veriler üzerinde herhangi bir tahrifat yapılmamış ve bu çalışma herhangi başka bir akademik yayın ortamına değerlendirme için gönderilmemiştir.

\section{KAYNAKLAR}

Arabacı, B. (2010). Müşteri hizmetleri ve CRM. 2. Baskı. İstanbul: Kum Saati Yayın Dağıtım Ltd. Şti.

Afthinos, Y., Theodorakis, N.D. \& Nassis, P. (2005). Customers' expectations of service in Greek fitness centers'. Managing Service Quality, 15(3), 245-258. DOI: https://doi.org/10.1108/09604520510597809.

Atal1, L. (2015). Büyükşehir belediyeleri stratejik planlarında spor ile ilgili amaç ve hedeflerin analizi. Spor Yönetimi ve Bilgi Teknolojileri Dergisi, 10(1), 48-56.

Berry, L., Parasuraman, A. \& Zeithaml, V.A. (1994). Improving service quality in America: Lessons learned. Academy of Management Perspectives, 8(2), 32-52. DOI: https://doi.org/10.5465/ame.1994.9503101072.

Cronin, J.J. \& Taylor, S.A. (1992). Measuring service quality: A reexamination and extension. Journal of Marketing, 56(3), 55-68. DOI: https://doi.org/10.2307/1252296.

Cronin, J.J. \& Taylor, S.A. (1994). SERVPERF versus SERVQUAL: Reconciling performance-based and perceptions-minus-expectations measurement of service quality. Journal of Marketing, 58(1), 125-131. DOI: https://doi.org/10.2307/1252256.

Eroğlu, E. (2012). Türkiye'de 1990-2010 yılları arasında spor yönetiminde meydana gelen gelişmeler. Beden Eğitimi ve Spor Anabilim Dalı Yüksek Lisans Tezi, İnönü Üniversitesi.

Grönroos, C. (1984). A service quality model and its marketing implementations. European Journal of Marketing, 18(4), 36-44. DOI: https://doi.org/10.1108/EUM0000000001784.

Gürbüz, B. (2003). Reliability and validity of the Turkish version of the Service Quality Assessment Scale. Master Thesis, Middle East Technical University Social Sciences Institute.

Gürbüz, B., Koçak, S. ve Lam, E. T. C. (2005). Hizmet Kalitesi Değerlendirme Ölçeği’nin Türkçe versiyonunun güvenirliği ve geçerliği. Eğitim ve Bilim, 30(138), 70-77.

Koçak, O., Arslan, H. ve Eti, S. (2017). Belediyelerde sosyal politika uygulamaları ve Pendik Belediyesi örneği. OPUS-Uluslararası Toplum Araştırmaları Dergisi, 7(12), 119-144.

Lam, E.T.C., Zhang, J.J. \& Jensen, B.E. (2005). Service quality assessment scale (SQAS): an instrument for evaluating service quality of health-fitness clubs. Measurement in Physical Education and Exercise Science, 9(2), 79-111. DOI: https://doi.org/10.1207/s15327841mpee09022.

MacKay, K.J. \& Crompton, J.L. (1988). A conceptual model of consumer evaluation of recreation service quality. Leisure Studies, 7, 41-49. DOI: https://doi.org/10.18999/JPRA-2017-V35-14-7922.

Negiz, N. (2011). Sosyal yardım ve sosyal hizmet faaliyetleri açısından Isparta Belediyesi: Farkındalık, yararlanma ve değerlendirme açısından bir araştırma. Süleyman Demirel Üniversitesi İktisadi ve İdari Bilimler Fakültesi Dergisi, 16(2), 323-341.

Parasuraman, A., Zeithaml, V.A. \& Berry, L.L. (1985). A conceptual model of service quality and its implications for future research. Journal of Marketing, 49(4), 41-50. 
Tanrıkulu, G. ve Ekici, S. (2020). Yerel yönetimlerin spor tesislerinden faydalanan yöre halkının hizmet kalitesi beklentisi ve algısına yönelik bir inceleme: Keçiören Belediyesi örneği. Spor Bilimleri Araştırmaları Dergisi, 5(1), 15-26.

Parasuraman, A., Zeithaml, V.A. \& Berry, L.L. (1988). SERVQUAL: A multiple-item scale for measuring consumer perceptions of service quality. Journal of Retailing, 64(1), 12-40.

Parasuraman, A., Zeithaml, V.A. \& Berry, L.L. (1994). Reassessment of expectations as a comparison standard on measuring service quality: Implications for further research. Journal of Marketing, 58(1), 111-124. DOI: https://doi.org/10.2307/1252255.

Rueangthanakiet, P. (2008). Members' satisfaction of fitness service quality: a case study. A Master's Project, Master of Arts Degree in Business English for International Communication at Srinakharinwirot University, California.

Usta, R. ve Memiş, L. (2010). Belediye hizmetlerinde kalite: Giresun Belediyesi örneği. Süleyman Demirel Üniversitesi Íktisadi ve İdari Bilimler Dergisi, 15(2), 333- 355.

Yetim, A. (2018). Yönetim ve spor. 1.Bask1. Ankara: Berikan Ofset Matbaa.

Yıldız, S.M. (2008). Spor hizmetleri kalitesini değerlendirmede kullanılabilecek hizmet kalitesi modelleri ve ölçüm araçları. Gazi Beden Eğitimi ve Spor Bilimleri Dergisi, 13(3), 35-48.

Yıldız, S.M. (2009). Service quality models in participant sports services. Ege Academic Review, 9(4), 12131224.

Yıldız, S.M. ve Tüfekçi, Ö. (2010). Fitness merkezi müşterilerinin hizmet kalitesine yönelik beklenti ve algılarının değerlendirilmesi. Balıkesir Üniversitesi Sosyal Bilimler Enstitüsü Dergisi, 14(24), 1-11.

Yıldız, S.M. (2011a). İçsel pazarlama, iş tatmini ve örgütsel bağl1lık ilişkisi: Spor okullarında görev yapan antrenörler üzerine bir inceleme. Selçuk Üniversitesi Beden Eğitimi ve Spor Bilim Dergisi, 13(2), 216225.

Yıldız, S.M. (2011b). Spor hizmeti sunan kamu kurumlarında lider üye etkileşimi ve örgütsel vatandaşlık davranışı iliş̧isi. Selçuk Üniversitesi Beden Eğitimi ve Spor Bilim Dergisi, 13(3), 323-329.

Yıldız, K. (2018). Yerel yönetimler ve kalkınma planları çerçevesinde spor hizmetleri. Gaziantep Üniversitesi Spor Bilimleri Dergisi, 3(1), 75-76.

Yıldız, K., Polat, E., Sözmezoğlu, U. ve Çokpartal, C. (2016). Fitness merkezi üyelerinin algıladıkları hizmet kalitesinin belirleyicileri üzerine bir analiz. Niğde Üniversitesi Beden Eğitimi ve Spor Bilimleri Dergisi, 10(3), 453-464.

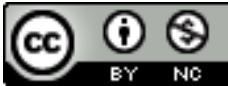

Bu eser Creative Commons Atıf-Gayri Ticari 4.0 Uluslararası Lisansı ile lisanslanmıştır. 